Agro-Science Journal of Tropical Agriculture, Food, Environment and Extension Volume 15 Number 2 May 2016 pp. $1-8$

ISSN 1119-7455

\title{
EFFECTS OF PHOSPHORUS AND SULPHUR ON DRY MATTER YIELD OF MAIZE (Zea mays) IN SOME SOILS AT ABEOKUTA, OGUN STATE, NIGERIA
}

\author{
${ }^{* 1}$ Ogunsola, K.E. and ${ }^{2}$ Adetunji, M.T. \\ ${ }^{1}$ Department of Biological Sciences, Bells University of Technology, Ota, Ogun State, Nigeria \\ ${ }^{2}$ Department of Soil Science \& Land Mgt., Federal University of Agriculture, Abeokuta, Ogun State, Nigeria \\ *Corresponding author's email: kayodeogunsola@yahoo.co.uk
}

\begin{abstract}
Phosphorus and Sulphur fertilizers are important for increasing the productivity of maize in most parts of Nigeria. A screen-house experiment was conducted to investigate the effects of phosphorus $(P)$ and sulphur $(S)$ on maize dry-matter yield (MDY) in soils of five locations (Obantoko I, II, Alabata I, II, and III) in Abeokuta, Ogun State of Nigeria. Three levels of sulphur $\left(0,10\right.$ and $\left.20 \mathrm{~kg} \mathrm{~S} \mathrm{ha}^{-1}\right)$ and phosphorus $\left(0,30\right.$ and $\left.45 \mathrm{~kg} \mathrm{P} \mathrm{ha}^{-1}\right)$ were evaluated in a $3 \times 3 \times 5$ factorial experiment laid in Completely Randomised Design with three replications. Pre-planting analyses were performed to determine soil $\mathrm{pH}$, particle size, organic matter, $\mathrm{K}, \mathrm{Na}, \mathrm{P}$ and $\mathrm{S}$. Eight weeks after planting, maize parts above the soil level were harvested, oven-dried and dry-matter yield were computed and recorded. Application of $S$ fertilizer appears not to be critical to maize production in the study areas since singly added $S$ did not produce significant increase in biomass yield. In contrast, applied $P$ significantly increased MDY in all the soils except Obantoko II, which already contained high amount of $P$ sufficient for maize yield. Both synergism (Alabata II and III) and antagonistic (Alabata I) interactions were observed between $P$ and $S$ on MDY without any interactive effect in Obantoko I soil. Application rate of 30-45 $\mathrm{kg}$

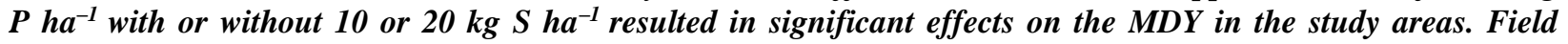
studies on effects of $P$ and $S$ on maize grain yield are recommended.
\end{abstract}

Key words: available P and S, maize productivity, Nigeria soils, biomass, fertilizers

\section{INTRODUCTION}

Maize is the third most important cereal crops in the world next to wheat (Triticum aestivum L.) and rice (Oryza sativum L.) (Muhammad et al., 2015). It is grown extensively in the temperate, sub-tropical and tropical regions of the world. World total maize production is 1.04 billion tonnes from which USA is the highest $(50.4 \%)$ producer producing 361 million tonnes, followed by China and Brazil (FAO, 2014). Africa produces 77.6 million tonnes of which $10.8 \mathrm{~m}$ tonnes is from Nigeria, harvested from 5.9 million ha land area (FAOSTAT, 2014). Maize is a popular cereal in the tropics. It is consumed as a staple food to supply energy to man (Onasanya et al., 2009). In Nigeria, maize is a staple food and one of the most abundant crops (Ayinde et al., 2015). It is produced in all parts of the country, from the north to the south (Abdulrahaman and Kolawole, 2006). Traditionally, it was mostly grown in the forest ecology in Nigeria but large scale production has shifted to the savanna zone, especially the Northern Guinea savanna (Olaniyan, 2015). Maize has been rated the second grown food crop in Nigeria after cassava, followed by sorghum and rice (FAO, 2013). Its production has increased in the guinea savanna ecology, owing to the adoption of high yielding and adapted varieties and increased use of fertilizer (Fajemisin, 1991). As a food crop, it is prepared and consumed in a multitude of ways which vary from region to region or from one ethnic group to the other (Abdulrahaman and Kolawole, 2006). It is used in livestock feeds (Olaniyan, 2015; Fabunmi and Agbonlahor, 2012), and also serves as raw material for many agro-based industries (Iken and Amusa, 2004). Maize production plays key role toward sustainable development of rural economy, food security and poverty reduction in Nigeria (Oyakhilomen, 2014). Maize is a dominant component of the crop production system in Abeokuta in the derived savanna zone which is part of the grain belt of Nigeria (Fabunmi and Agbonlahor, 2012). Importance of maize in this region is tied to its uses both as staple food and in formulating livestock feed (Fabunmi and Agbonlahor, 2012). 
Despite its importance, maize yield is still low in Nigeria due to biotic, abiotic and agronomic factors (Olaniyan, 2015; Onasanya et al., 2009). The average yield in Nigeria is $1,845 \mathrm{~kg} \mathrm{ha}^{-1}$ (FAO, 2014). Parts of the major abiotic causes of the low yield in Africa are declining soil fertility and insufficient use of fertilizers, resulting in severe nutrient depletion of soils (Buresh et al., 1997). In order to achieve optimum productivity of maize crop, balanced soil nutrients are required. Increased in human population growth rate in Nigeria has lead into short fallow period. Continuous cultivation of crops on the same soil has also resulted in increased rate of rapid loss of soil fertility (Uzoh et al., 2015). This has necessitated the supplementing of soil natural fertility with fertilizers to replenish the soil for optimum yield. Also, the increasingly high cost of mineral fertilizers in crop production had necessitated an investigation into the optimum fertilizer rate for profitable maize production in Nigeria (Adekayode and Ogunkoya, 2010). Today, commercial agriculture without the use of fertilizers is not yet achievable in Nigeria. Several studies had revealed the need for application of various nutrient elements such as nitrogen $(\mathrm{N})$, phosphorus (P), potassium (K), sulphur (S), and some trace elements in order to boost crop productivity in Nigeria (Ayodele and Omotosho, 2008; Adekayode and Ogunkoya, 2010; Isitekhale et al., 2013).

The $\mathrm{P}$ is the second major nutrient essential for plant growth (Muhammad et al., 2015) and one of the most limiting plant nutrients in crop production next to $\mathrm{N}$, in most agricultural soils in Nigeria (Akande et al., 2010). It plays an important role in many physiological processes that occur within a developing and maturing plant. It is involved in enzymatic reactions in plant, essential for cell division, important for seed and fruit formation, affects the quality of the grains and may increase the plant resistance to diseases (Onasanya et al., 2009). The P deficient plants show stunting, dark green or blue green foliage, often with a purple tint on the leaves and stem, starting from lower leaves. Application of $\mathrm{P}$ had showed significant effects on grain yield, dry-matter yield, number of leaves and leaf area (Ali et al., 2002; Ayub et al., 2002; Yusuf et al., 2003). Low soil $\mathrm{P}$ availability is well established in Nigeria (Adepetu, 1993). Application rate of 120 $\mathrm{kg} \mathrm{N} \mathrm{ha}^{-1}$ and $40 \mathrm{~kg} \mathrm{P} \mathrm{ha}^{-1}$ had significantly increased the growth and yield of maize in Southwestern Nigeria (Adetunji, 1997; Onasanya et al., 2009).

The $\mathrm{S}$ is also becoming increasingly important as a yield limiting factor in many Nigeria soils (Adetunji and Adepetu, 1989). The continuous use of non-sulphur nitrogen fertilizers has generated $S$ deficiency problem. The $\mathrm{S}$ is recognized as the fourth major nutrient after $\mathrm{N}, \mathrm{P}$ and $\mathrm{K}$. It plays a key role in the synthesis of amino acids cysteine and methionine which are essential components of protein and useful in secondary metabolism. It has beneficial effects by lowering soil $\mathrm{pH}$ and improving physical condition of the soil (Choudhary and Das, 1996). Increasing level of $\mathrm{S}$ progressively enhanced the average total $\mathrm{N}$ uptake by maize and this increase in $\mathrm{N}$ uptake may be attributed to increase in $\mathrm{N}$ content of plant and dry matters yield due to increasing S levels (Jaliya et al., 2012). Ray and Mughogho (2000) reported that $S$ is a secondary nutrient taken up by most grain crops in amount namely 10 to $30 \mathrm{~kg} \mathrm{ha}^{-1}$. Its deficiency is reported to be higher in savanna area than in the forest zone due to very long period of plant burning during which sulphur in the grass and other plant goes up in smoke as sulphur dioxide (Adetunji and Adepetu, 1989; Tandon, 1989).

Interaction between $\mathrm{P}$ and $\mathrm{S}$ has been observed. Several studies reported both synergistic and antagonistic relationship between $\mathrm{P}$ and $\mathrm{S}$, depending on their rate of application and crop species. Synergistic effect of applied P and S was observed by Kumawat (2004). Antagonistic relationship between $\mathrm{P}$ and $\mathrm{S}$ was observed in mung and wheat (Islam et al., 2006) and in maize (Muhammad et al., 2015). This interaction influences the absorption of sulphur, in form of sulphate, in the soil (Adetunji, 1991). It is important to study the level of soil $\mathrm{S}$ and $\mathrm{P}$ required for optimum crop yield and the likely effect of $S$ application on the crop utilization of $\mathrm{P}$. This study was carried out to determine the optimum level of $P$ and $\mathrm{S}$ fertilizer requirements and their interaction on the dry-matter yield of maize in soils of some selected locations in Abeokuta, Ogun State.

\section{MATERIALS AND METHODS Soil Sample Collection}

The pot experiment was conducted at the Department of Soil Science and Land Management, Federal University of Agriculture Abeokuta (FUNAAB), Ogun State, Nigeria. Bulk samples of surface soil (0$15 \mathrm{~cm}$ depth) were collected from five locations in Odeda Local Government Area, Abeokuta. Two soil samples were collected from Obantoko area; Obantoko I and II in Abeokuta (Obantoko I is a farm land located about $2 \mathrm{~km}$ away from the IbadanAbeokuta Road, Somorin area of Obantoko and Obantoko II is in Alogi area of Obantoko located about $3 \mathrm{~km}$ off Ibadan-Abeokuta Road). Three samples were from different locations in Alabata area (Alabata I, II, and III) all within FUNAAB campus (Alabata I is the experimental farm beside College of Plant Science and Crop Production (COLPLANT), Alabata II is the land area beside the FUNAAB 
Student Centre and Alabata III is the FUNAAB Teaching and Research Farm at Alabata). A total of 5 soil samples were collected from the five locations, all of which are within Ekiti soil series.

\section{Soil Preparation for Planting}

Soil samples were air-dried, ground and passed through a 2-mm sieve. Soil samples from each of the five locations were analysed to determine their physical and chemical properties before planting. Two kg of each soil was weighed into planting pots. There were three rates of S: 0,10 and $20 \mathrm{~kg} \mathrm{~S} \mathrm{ha}^{-1}$ supplied as elemental $\mathrm{S}$ and three rates of P: 0,30 and $45 \mathrm{~kg} \mathrm{P} \mathrm{ha}^{-1}$ applied as NPK 20-10-10. The two applied rates of NPK supplied the $30 \mathrm{~kg} \mathrm{P} \mathrm{ha}^{-1}(0.57$ $\mathrm{g}$ per pot) and $45 \mathrm{~kg} \mathrm{P} \mathrm{ha}^{-1}(0.87 \mathrm{~g}$ per pot) to the soils which also supplied the $\mathrm{N}$ and $\mathrm{K}$ required for maize yield. After two weeks of planting, two rates of Nitrogen $200 \mathrm{~kg} \mathrm{~N} \mathrm{ha}^{-1}$ and $64 \mathrm{~kg} \mathrm{~N} \mathrm{ha}^{-1}$, as Urea, was applied to all pots receiving no phosphorus $(0 \mathrm{~kg}$ $\mathrm{P} \mathrm{ha}^{-1}$ ) and those receiving $35 \mathrm{~kg} \mathrm{P} \mathrm{ha}^{-1}$ respectively to supply the basal dose of $\mathrm{N}$. These additional rates of $\mathrm{N}$ thus provided a uniform supply $200 \mathrm{~kg} \mathrm{~N} \mathrm{ha}^{-1}$ to all the pots. The experiments were in a Completely Randomized Design (CRD) laid in 3 (rates of $\mathrm{S}$ ) $\times 3$ (rates of $\mathrm{P}$ ) $\times 5$ (soils) factorial with three replicates making 27 pots per soil and 135 experimental units. After fertilizer application into the soils, maize cultivar Suwan1 obtained from the Institute of Agricultural Research and Training (IAR\&T) was planted in each pot at three seed per pot and thinned to two seedlings per pot two weeks after planting. Maintenance practices like watering and weeding were carried out as required.

\section{Soil Laboratory Analysis}

Soil samples were taken for pre-planting laboratory analysis. Soil $\mathrm{pH}$ was measured by glass electrode $\mathrm{pH}$ meter in 1:2 soil-water ratio. Organic matter content was determined using Walkley and Black (1934) procedure. Particle size analysis of the soils was by pipette method with sodium-hexameta-phosphate as dispersant (Gee and Bauder, 1986). The $\mathrm{S}$ in the soil was extracted using $0.01 \mathrm{M} \mathrm{Ca}\left(\mathrm{H}_{2} \mathrm{PO}_{4}\right)_{2}$ extractant and determined turbidimetrically by Chesin and Yien (1951) procedure. The P was extracted by Bray-1 procedure (Bray and Kurtz, 1945) and determined colourimetrically using molybdenum blue method. Exchangeable cations $\mathrm{K}$ and $\mathrm{Na}$ were extracted using neutral 1M Ammonium Acetate and then determined by flame photometry (Thomas, 1982).

\section{Data Collection and Analysis}

Eight weeks after planting, the plant parts above the soil level were harvested and oven-dried at $65^{\circ} \mathrm{C}$ for 48 hours. Each maize plant was then weighed to obtain the dry matter yield. Data were analyzed with analysis of variance (ANOVA) using SAS software version 9.3 (SAS, 2010). Means were compared using Duncan's Multiple Range Test.

\section{RESULTS}

\section{Pre-treatment soil analysis}

Physico-chemical properties of the soils before fertilizer applications are shown in Table 1. The soils ranged from being slightly acidic to slightly alkaline with $\mathrm{pH}$ value from 5.9 in Alabata II to 7.2 in Obantoko II soils. Organic matter content of the soils ranged from low (1.3\%) in Alabata II to high (3.2\%) in Obantoko II. Available $\mathrm{S}$ of the surface $(0-15 \mathrm{~cm})$ soils were low, ranging from $1.25 \mathrm{mg} \mathrm{kg}^{-1}$ in Alabata II to $3.70 \mathrm{mg} \mathrm{kg}^{-1}$ in Obantoko I while the $\mathrm{K}$ content was higher in Obantoko II $\left(0.37 \mathrm{cmol}(+) \mathrm{kg}^{-1}\right)$ than in other soils. Available soil $\mathrm{P}$ values ranged from low $\left(5.15 \mathrm{mg} \mathrm{kg}^{-1}\right)$ in Alabata I to high $\left(18.50 \mathrm{mg} \mathrm{kg}^{-1}\right)$ in Obantoko II. The soils textural class range from sandy loam in Obantoko II through loamy sand in Alabata I, II and III to sand in Obantoko I.

\section{Effect of Single Application of $P$ and $S$ on Maize Dry Matter Yield}

The effects of single application of different rates of $\mathrm{P}$ and $\mathrm{S}$ on dry matter yield are presented in Fig. 1 and Table 2. Maize dry matter yield (MDY) produced by either of the two rates of $\mathrm{S}$ fertilizer $(0 \mathrm{P}+10 \mathrm{~S}$ and $0 \mathrm{P}+20 \mathrm{~S} \mathrm{~kg} \mathrm{ha}^{-1}$ ) were not significantly higher than that of the control $(0 \mathrm{P}+0 \mathrm{~S})$ in the soils from the five locations. For instance, all three treatments of $\mathrm{S}$ rates $\left(0 \mathrm{P}+0 \mathrm{~S}, 0 \mathrm{P}+10 \mathrm{~S}\right.$ and $\left.0 \mathrm{P}+20 \mathrm{~S} \mathrm{~kg} \mathrm{ha}^{-1}\right)$ produced similar DMY of maize of $2.0 \pm 0.4,2.2 \pm 0.1$ and $2.1 \pm 0.5 \mathrm{~g}$ per plant, respectively in Obantoko I soil and similar trend was observed in the soils of the remaining four locations.

Table 1: Physico-chemical properties of the soils from pre-treatment analysis

\begin{tabular}{|c|c|c|c|c|c|c|c|c|c|c|}
\hline \multirow{3}{*}{ Location } & \multirow{3}{*}{$\mathrm{pH}$} & \multirow{3}{*}{$\begin{array}{c}\text { Organic } \\
\text { matter } \\
(\%)\end{array}$} & \multicolumn{2}{|c|}{ Exchangeable } & \multirow{2}{*}{ Available } & \multirow{2}{*}{$\mathrm{S}$} & \multicolumn{4}{|c|}{ Particle size } \\
\hline & & & $\mathrm{K}$ & $\mathrm{Na}$ & & & Sand & Silt & Clay & \multirow[t]{2}{*}{ Textural name } \\
\hline & & & \multicolumn{2}{|c|}{$\mathrm{cmol}(+) \mathrm{kg}^{-1}$} & \multicolumn{2}{|c|}{$\mathrm{mg} \mathrm{kg}^{-1}$} & \multicolumn{3}{|c|}{$(\%)$} & \\
\hline Obantoko I & 6.2 & 2.3 & 0.11 & 0.01 & 16.1 & 3.7 & 89 & 3 & 8 & Sand \\
\hline Alabata I & 6.3 & 2.5 & 0.09 & 0.01 & 5.15 & 2.22 & 77 & 16 & 7 & Loamy sand \\
\hline Alabata II & 5.9 & 1.3 & 0.07 & 0.01 & 6.06 & 1.25 & 84 & 9 & 7 & Loamy sand \\
\hline Alabata III & 6.0 & 2.3 & 0.07 & 0.01 & 5.7 & 2.35 & 85 & 9 & 6 & Loamy sand \\
\hline
\end{tabular}




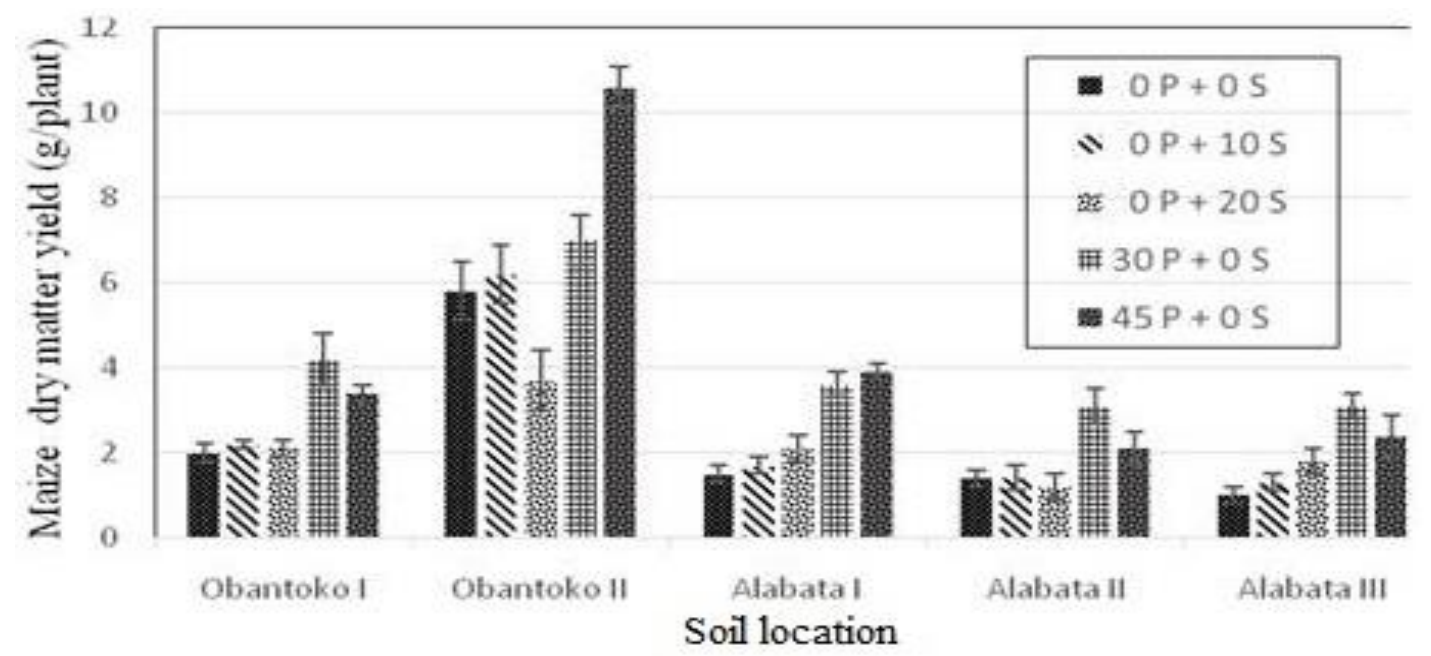

Figure 1: Effect of single application of different rates of phosphorus and sulphur on dry matter yield of maize

On the contrary, the two rates of the singly applied $\mathrm{P}(30 \mathrm{P}+0 \mathrm{~S}$ and $45 \mathrm{P}+0 \mathrm{~S})$ resulted in significantly $(p \leq 0.05)$ higher dry matter yield relative to the control in all the soils except Obantoko II. Alabata I soil supplied with $45 \mathrm{~kg} \mathrm{ha}^{-1}$ resulted in $3.9 \pm 0.4 \mathrm{~g}$ biomass yield which was significantly higher than that of the same soil without of $\mathrm{P}$ $(1.5 \pm 0.4 \mathrm{~g})$ application (Table 2). The two single application rates of $\mathrm{P}$ yielded higher maize biomass than the two applied rates of S. However, comparing the general effect of the $\mathrm{P}$ and $\mathrm{S}$ among the five soils, highest dry matter yield response per plant was obtained in the soil from Obantoko II, followed by that of Obantoko I while lowest yields were produced in the three soils from Alabata areas (Fig. 2).

\section{Interactive Effects of $P$ and $S$ on Maize DMY}

Results of single and interactive effects of $\mathrm{P}$ and $\mathrm{S}$ on maize DMY are shown in Table 2. The two rates of $P$ with or without $S$ resulted in significant increase in the DMY in all soils except Obantoko II. Highest biomass yield was produced by $45 \mathrm{~kg} \mathrm{P} \mathrm{ha}^{-1}+10 \mathrm{~kg}$ $\mathrm{S} \mathrm{ha}^{-1}$ in Obantoko I soil, which was similar to those produced by either 30 or $45 \mathrm{~kg} \mathrm{P}^{-1}$ with or without S. For Alabata I soil, $45 \mathrm{~kg} \mathrm{P} \mathrm{ha}^{-1}+20 \mathrm{~kg} \mathrm{~S} \mathrm{ha}^{-1}$ showed the highest yield, which was also achieved with $45 \mathrm{~kg} \mathrm{P} \mathrm{ha}^{-1}$ with or without $10 \mathrm{~kg} \mathrm{~S} \mathrm{ha}^{-1}$ and at $30 \mathrm{~kg} \mathrm{P} \mathrm{ha}{ }^{-1}$ without S. Both synergy and antagonism were observed between $P$ and S on MDY. Synergistic interaction was observed between $\mathrm{P}$ and $\mathrm{S}$ on maize biomass in Alabata II and III soils where single application of $45 \mathrm{~kg} \mathrm{P}^{\mathrm{Pa}}{ }^{-1}$ did not increase DMY unless combined with 10 or $20 \mathrm{~kg} \mathrm{~S} \mathrm{ha}^{-1}$. The synergy produced by the addition of $\mathrm{S}$ to $\mathrm{P}$ in Alabata II caused a significant increase in MDY from $2.1 \pm 1.2$ following addition of $45 \mathrm{~kg} \mathrm{P} \mathrm{ha}^{-1}$ to $2.8 \pm 0.4 \mathrm{~g}$ and $4.2 \pm 0.7 \mathrm{~g}$ from the applied $45 \mathrm{~kg} \mathrm{P} \mathrm{ha}^{-1}+10 \mathrm{~kg} \mathrm{~S} \mathrm{ha}^{-1}$ and $45 \mathrm{~kg} \mathrm{P} \mathrm{ha}^{-1}+20 \mathrm{~kg} \mathrm{~S}^{-1}$ respectively. A similar significant increase following addition of 10 and 20 $\mathrm{kg} \mathrm{S} \mathrm{ha}{ }^{-1}$ was observed in Alabata III. Contrarily, antagonism was observed between $\mathrm{P}$ and $\mathrm{S}$ in Alabata I. Although $30 \mathrm{~kg} \mathrm{P} \mathrm{ha}^{-1}$ applied solely $(3.1 \pm 1.2 \mathrm{~g})$ or combined with $10 \mathrm{~S} \mathrm{~kg} \mathrm{ha}^{-1}(3.3 \pm 1.9 \mathrm{~g})$ and $20 \mathrm{~S} \mathrm{~kg}$ $\mathrm{ha}^{-1}(3.4 \pm 0.4 \mathrm{~g})$ resulted in similar high biomass yield in Alabata II (Table 2), the same rate of $\mathrm{P}$ and $\mathrm{S}$ (30 $\mathrm{P}$ $+10 \mathrm{~S} \mathrm{~kg} \mathrm{ha}^{-1}$ and $30 \mathrm{P}+20 \mathrm{~S} \mathrm{~kg} \mathrm{ha}^{-1}$ ) produced an antagonistic effect that resulted in significant reduction in maize DMY to $1.4 \pm 0.6 \mathrm{~g}$ and $1.7 \pm 0.9 \mathrm{~g}$ in Alabata I soil compared with yield $(3.6 \pm 0.7 \mathrm{~g})$ produced by single application of $30 \mathrm{~kg} \mathrm{P} \mathrm{ha}^{-1}$.

Table 2: Effects of phosphorus $(\mathrm{P})$ and sulphur $(\mathrm{S})$ on maize dry matter yield in five soils from Abeokuta, Ogun State

\begin{tabular}{lccccc}
\hline \multirow{2}{*}{$\begin{array}{l}\text { Soil S and P rates } \\
\left(\mathrm{kg} \mathrm{ha}^{-1}\right)\end{array}$} & Obantoko I & Obantoko II & Alabata I & Alabata II & Alabata III \\
\hline $0 \mathrm{P}+0 \mathrm{~S}$ & $2.0 \pm 0.4 \mathrm{~b}$ & $5.8 \pm 4.0 \mathrm{a}$ & $1.5 \pm 0.4 \mathrm{c}$ & $1.4 \pm 0.4 \mathrm{~cd}$ & $1.0 \pm 0.4 \mathrm{~b}$ \\
$30 \mathrm{P}+0 \mathrm{~S}$ & $4.2 \pm 2.9 \mathrm{ab}$ & $7.0 \pm 3.1 \mathrm{a}$ & $3.6 \pm 0.7 \mathrm{abc}$ & $3.1 \pm 1.2 \mathrm{abc}$ & $3.1 \pm 0.9 \mathrm{ab}$ \\
$45 \mathrm{P}+0 \mathrm{~S}$ & $3.4 \pm 0.5 \mathrm{ab}$ & $10.6 \pm 2.1 \mathrm{a}$ & $3.9 \pm 0.4 \mathrm{ab}$ & $2.1 \pm 1.2 \mathrm{bcd}$ & $2.4 \pm 2.0 \mathrm{~b}$ \\
$0 \mathrm{P}+10 \mathrm{~S}$ & $2.2 \pm 0.1 \mathrm{~b}$ & $6.2 \pm 4.0 \mathrm{a}$ & $1.7 \pm 0.2 \mathrm{bc}$ & $1.4 \pm 0.6 \mathrm{~cd}$ & $1.3 \pm 0.5 \mathrm{~b}$ \\
$30 \mathrm{P}+10 \mathrm{~S}$ & $4.1 \pm 1.5 \mathrm{ab}$ & $8.0 \pm 1.5 \mathrm{a}$ & $1.4 \pm 0.6 \mathrm{c}$ & $3.3 \pm 1.9 \mathrm{ab}$ & $2.1 \pm 0.5 \mathrm{~b}$ \\
$45 \mathrm{P}+10 \mathrm{~S}$ & $4.9 \pm 0.8 \mathrm{a}$ & $10.2 \pm 3.6 \mathrm{a}$ & $3.3 \pm 0.6 \mathrm{abc}$ & $2.8 \pm 0.4 \mathrm{abcd}$ & $5.0 \pm 1.6 \mathrm{a}$ \\
$0 \mathrm{P}+20 \mathrm{~S}$ & $2.1 \pm 0.5 \mathrm{~b}$ & $3.7 \pm 4.0 \mathrm{a}$ & $2.1 \pm 0.8 \mathrm{bc}$ & $1.2 \pm 0.6 \mathrm{~d}$ & $1.8 \pm 0.8 \mathrm{~b}$ \\
$30 \mathrm{P}+20 \mathrm{~S}$ & $2.9 \pm 0.7 \mathrm{ab}$ & $8.8 \pm 5.0 \mathrm{a}$ & $1.7 \pm 0.9 \mathrm{bc}$ & $3.4 \pm 0.4 \mathrm{ab}$ & $2.0 \pm 0.5 \mathrm{~b}$ \\
$45 \mathrm{P}+20 \mathrm{~S}$ & $3.1 \pm 0.6 \mathrm{ab}$ & $5.2 \pm 1.7 \mathrm{a}$ & $5.0 \pm 3.2 \mathrm{a}$ & $4.2 \pm 0.7 \mathrm{a}$ & $5.5 \pm 2.5 \mathrm{a}$ \\
\hline
\end{tabular}

Values are means \pm SE. Means followed by the same letter in each column are not significantly $(p \leq 0.05)$ different. 


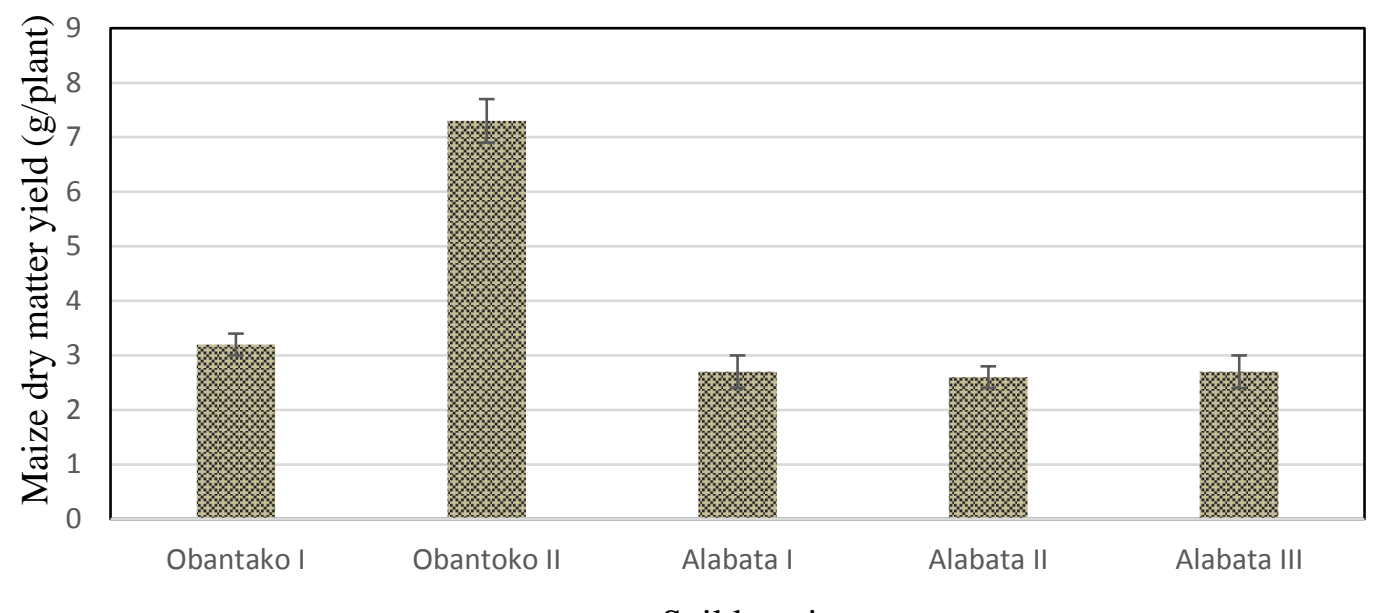

Soil location

Figure 2: Effect of soils with phosphorus and sulphur applications on dry matter yield of maize

\section{DISCUSSION}

The beneficial effects of fertilizer application on soils for a sustainable food crop production has made the need for information in fertilizer supply and use for increased food production desirable (Adekayode and Ogunkoya, 2010). In this study, all the soils were slightly acid to neutral (pH 5.9 to 7.2) which is good for most arable crops (Ayodele and Omotosho, 2008).Based on the criteria for soil test interpretation and soil fertility classes established for Maize in South-Western Nigeria (Agboola and Ayodele, 1985; FMANR, 1990), the organic matter content was low in Alabata II, medium in Obantoko I, Alabata I and III but high in Obantoko II soil. The low organic matter content of Alabata II may be due to previous cropping on the soil without nutrient replenishment.

Despite the low level $\left(<5 \mathrm{mg} \mathrm{kg}^{-1}\right)$ of available $\mathrm{S}$ in all the soils, application of $\mathrm{S}$ without $\mathrm{P}$ fertilizer did not result in significant increase in maize dry matter yield. This may be due to medium level of organic matter content plus the adequate supply of $\mathrm{N}$ to all the soils. Such result is also conceivable since $\mathrm{S}$ content depends on level of organic matter content of the soil because mineralization of organic matter releases S into the soil (Weil and Mughogho, 2000). Similar effect of S has been reported in (Wortmann et al., 2006a,b, 2009; Shapiro et al., 2003). Also, it was reported that response to applied $\mathrm{S}$ is not likely on sandy soils with more than $1 \%$ soil organic matter (Wortmann et al., 2009). However, a contrary result was observed by Jaliya et al., (2015) where $5-15 \mathrm{~S} \mathrm{~kg}$ $\mathrm{ha}^{-1}$ produced high maize grain yield in Zaria, Nigeria. Similar observation was reported in Malawi, where applied $\mathrm{S}$ rates of $5-10 \mathrm{~kg} \mathrm{ha}^{-1}$ resulted in optimum maize grain yield (Weil and Mughogho, 2000).The highest MDY was observed in Obantoko II soil. This result was not surprising since the soil showed a high fertility status from pre-treatment test, containing high organic matter, $\mathrm{K}$ and $\mathrm{P}$ when compared with the critical soil nutrient levels established for maize in South-Western Nigeria (Agboola and Ayodele, 1985; FMANR, 1990). This soil was observed to be sandy loam while others were sand or loamy sand. Hence, consequent upon the high nutrient content of the Obantoko II soil, there was no significant effect of the added $\mathrm{P}$ and $\mathrm{S}$ either singly or mixed on the maize biomass yield. Also, $\mathrm{P}$ and $\mathrm{S}$ observed in the soils from both locations in Obantoko area were higher than that of soil samples from Alabata. We also observed that contrary to the single supply of $S$, the two single $P$ rates resulted in significant higher dry matter yield in all the soils except Obantoko II, which already contained adequate nutrients and in Alabata II and III where 45 $\mathrm{kg} \mathrm{P} \mathrm{ha}{ }^{-1}$ yielded high biomass only when $\mathrm{S}$ was applied. Increased maize grain yield to $\mathrm{P}$ application has been earlier reported from various studies in Nigeria (Adediran and Banjoko, 1995; Adetunji, 1997; Yusuf et al., 2003; Ayodele and Omotosho, 2008) and in other countries (Taalab et al., 2008; Wortmann et al., 2009). Similar observation on effect of $\mathrm{P}$ on maize grain yield has been reported for biomass yield. According to Akande et al. (2010), phosphate application enhanced dry matter yields of maize and cowpea in Ibadan, Nigeria.

The two applied $\mathrm{P}$ rates, with or without $\mathrm{S}$, resulted in significant increase in dry matter yield from all the soils except in Obantoko II. Findings from this study showsthat 30 to $45 \mathrm{~kg} \mathrm{P} \mathrm{ha}^{-1}$ with or without 10 or $20 \mathrm{~kg} \mathrm{Sha}^{-1}$ produced the highest MDY in the soils of the studied locations. Similar results have been reported. Phosphorus treatments individually or in combination with $\mathrm{S}$ yielded a significant increase in the dry matter yield and 
consequently the grain yield of maize plants (Taalab et al., 2008). Positive response of maize to low $\mathrm{P}$ application in the derived and Southern guinea savanna zones of Nigeria reported by Adediran and Banjoko (1995) showed that application of $40 \mathrm{~kg} \mathrm{P}$ ha $^{-1}$ appeared to be optimum. The increased grainyield observed in a part of Southern guinea savanna at $60 \mathrm{~kg} \mathrm{P}_{2} \mathrm{O}_{5} \mathrm{ha}^{-1}$ was not significantly different from that from $40 \mathrm{~kg} \mathrm{P}_{2} \mathrm{O}_{5} \mathrm{ha}^{-1}$ (Adediran and Banjoko 1995). Grain yield reduction in maize observed from higher $\mathrm{P}$ application (60 kg $\mathrm{P} \mathrm{ha}{ }^{-1}$ ) was suggested to be due to the increase in $\mathrm{P}$ from 40 to $60 \mathrm{~kg} \mathrm{P} \mathrm{ha}^{-1}$ (Onasanya et al., 2009).

Interactions of soil nutrient affect their availability to crops as an overabundance of one may result in deficiency of another (Karimizarchi et. al., 2014). The synergism (Alabata II and III soils) and antagonism (Alabata I soil) between $\mathrm{P}$ and $\mathrm{S}$ fertilizers on maize yield observed in this study are also in line with previous findings. Synergistic relationship was reported by Rajan et al. (1996) where treatments receiving phosphate fertilizer with $\mathrm{S}$ had higher dry matter and grain yield of maize than those without $\mathrm{S}$ application. It was also observed from other studies that treating rock phosphate with elemental $S$ resulted in a considerable increase in available $\mathrm{P}$ with time (Taalab et al., 2008). The effective utilization of $\mathrm{P}$ sources in combination with $\mathrm{S}$ was obvious because $\mathrm{S}$ decrease soil $\mathrm{pH}$, which helped in transformation of insoluble $\mathrm{P}$ to available form. This synergy between the two nutrient elements plus citric acid on improving maize yield through the solubilising effects of $S$ and citric acid has been reported, in which mixing the various $\mathrm{P}$ sources with $\mathrm{S}$ and/or citric acid significantly increased the $\mathrm{P}$ uptake by maize plants (Taalab et al., 2008). In addition, application of $P$ fertilizer results in increased anion adsorption sites, which releases sulphate ions into the solution (Tiwari and Gupta, 2006). The capacity of applied $\mathrm{S}$ to reduce soil $\mathrm{pH}$ and increase availability of other nutrients to plant has enhanced the synergy between $\mathrm{P}$ and $\mathrm{S}$. A previous report showed that application of elemental $\mathrm{S}$ at a rate of $0.5 \mathrm{~g} \mathrm{~S} \mathrm{~kg}^{-1}$ soil decreased soil $\mathrm{pH}$ value from 7.03 to 6.29 and significantly increased availability of $\mathrm{Mn}$ and $\mathrm{Zn}$ which resulted in a $45 \%$ increase in total MDY (Karimizarchi et al., 2014). Apart from the synergistic effect of $\mathrm{S}$ on $\mathrm{P}$, a number of studies also indicted synergism from combined application of $\mathrm{S}$ and $\mathrm{N}$ on maize (Fazli et al., 2008). Maize crop fertilized at the rate of $150 \mathrm{~kg} \mathrm{P} \mathrm{ha}^{-1}$ and $20 \mathrm{~kg} \mathrm{~S} \mathrm{ha}{ }^{-1}$ produced significantly maximum grain yield (Muhammad et al., 2004).

The observed antagonistic relationship between $\mathrm{P}$ and $\mathrm{S}$ has been earlier reported in mung and wheat (Islam et al., 2006) and in maize grain yield
(Muhammad et al., 2015).Studies have showed that $\mathrm{P}$ and $\mathrm{S}$ content in maize leaves indicated that higher level of $S\left(75 \mathrm{~kg} \mathrm{ha}^{-1}\right)$ resulted in low uptake of $\mathrm{P}$ and vice versa, indicating their antagonistic effect. This effect was displayed in the yield whereby maximum grain yield was obtained where higher dose of $\mathrm{P}$ along with lower level of $\mathrm{S}$ was beneficial (Muhammad et al., 2015). In related studies in some South-western Nigerian soils (Adetunji, 1991), phosphorus addition resulted in depression in sulphate adsorption in which when lime was added together with phosphorus, resulted in displacement of adsorbed sulphate, suggesting high leaching losses of sulphur in soils receiving high phosphorus fertilizer application. Application of $\mathrm{P}$ and $\mathrm{S}$ beyond a certain level also results in adverse effects on maize productivity depending on soil type. According to Karimizarchi et al. (2014) despite the inverse relationship between $\mathrm{S}$ and soil $\mathrm{pH}$, continued decreasing trend of soil $\mathrm{pH}$ by $\mathrm{S}$ became detrimental to crops as $\mathrm{pH}$ reduction to 3.93 resulted in significant loss of $57 \%$ total dry weight of maize. Increasing $S$ application beyond $45 \mathrm{~kg} \mathrm{ha}^{-1}$ also reduced the available $\mathrm{P}$ content in soil (Muhammad, 2015).Interaction between $P$ and $N$ on maize grain yield has also been reported. Response of maize plant to application of $\mathrm{N}$ and $\mathrm{P}$ fertilizers varies with crop varieties, location and availability of the nutrients and application of $120 \mathrm{~kg} \mathrm{~N} \mathrm{ha}+40 \mathrm{~kg} \mathrm{P} \mathrm{ha}^{-1}$ significantly enhanced maize grain yield in Southern Nigeria (Onasanya et al., 2009). Application of high rate of $\mathrm{P}$ was reported to be capable of causing nutrient imbalance and consequently yield depression of maize (Adediran and Banjoko, 1995). This implies that both antagonism and synergy do occur between $\mathrm{P}$ and $\mathrm{S}$ on their effects on dry matter and grain yield of maize and the interaction of these plant nutrients may affect the critical level of available $P$ and $S$ in soils and plants (Choudry and Das, 1996). The type of interaction between nutrients also depend on soil type since Obantoko I soil showed similar dry matter yield to $\mathrm{P}$ with or without $\mathrm{S}$ application. Higher level of $\mathrm{P}$ with lower $\mathrm{S}$ usually results in better maize yield (Muhammad et al., 2015; Adediran and Banjoko, 1995); however, optimum rates of $P$ and $S$ fertilizer for maize productivity vary with soil type.

\section{CONCLUSION}

Application of S fertilizer appears not to be critical to production of maize on the soils of the study areas. However, responses to $\mathrm{P}$ applications were observed. Our findings show that $\mathrm{P}$ rate of 30 or $45 \mathrm{~kg} \mathrm{P} \mathrm{ha}^{-1}$ with or without 10 or $20 \mathrm{~kg} \mathrm{Sha}^{-1}$ produced the maximum maize dry matter yield in the soils with the exception of soil of Obantoko II, where the effect of $\mathrm{P}$ application was not significant since the soil 
contain sufficient amount of P. Also, both synergistic and antagonistic relationship was observed between $\mathrm{P}$ and $\mathrm{S}$ based on soil type and this resulted in significant effects on the biomass yield of maize. Higher level of $\mathrm{P}$ with lower $\mathrm{S}$ rate synergistically enhanced maize yield. However, an optimum combination of the two nutrient elements must be determined for specific locations in order to avoid their antagonism and reduction in maize productivity. The observed optimum rate of $\mathrm{P}$ and $\mathrm{S}$ fertilizers is recommended for the soil of the study locations for high maize yield since interaction of the two nutrients affects their availability to plant. Meanwhile, for effective use of $\mathrm{P}$ and $\mathrm{S}$ fertilizers in the study areas, field studies on their single and interactive effects on maize grain yield are recommended.

\section{REFERENCES}

Abdulrahaman, A.A. and Kolawole, O.M. (2006). Traditional preparations and uses of maize in Nigeria. Ethnobotanical Leaflets, 10: 219-227

Adediran, J.A. and Banjoko, V.A. (1995). Response of Maize to Nitrogen, Phosphorus and Potassium fertilizers in the savanna zone of Nigeria. Commun. Soil Sci. Plant Anal., 26:593-606

Adekayode, F.O. and Ogunkoya, M.O. (2010). Effect of quantity and placement distances of inorganic 15-1515 fertilizer in improving soil fertility status and the performance and yield of maize in a tropical rain forest zone of Nigeria. America-Eurasian J. Agric. And Environ. Sci., 7(2): 122-129

Adepetu, J.A. (1993). Phosphorus fertilization of tropical crops In: Eszman, Mutscher and Franke (Eds.). Nutrient Supply of Tropical Crops. Institution of Tropical Agriculture. Leipzig Publ. pp. 211-238.

Adetunji, M.T. (1991). Effect of lime and phosphorus application on the sulphate adsorption capacity of southwestern Nigerian soils. Ife J. Agric. Res. 13: 1120

Adetunji, M.T. (1997). Phosphorus adsorption capacity of low activity clay soils of southwestern Nigeria and its usefulness in evaluating P requirement of Rice. Nutr. Cycling Agro. Ecosys. 47: 181-188

Adetunji, M.T. and J.A. Adepetu (1989). Sulphur fertilization requirements of Southwestern Nigerian soils. Ife J. of Agric Res., 11: 23-30

Agboola, A.A. and Ayodele, O.J. (1985). Prospects and problems using soil testing for adoption of fertilizer use in Ekiti-akoko Agricultural Development Project area. Proceedings of the Workshop on Appropriate Technologies for Farmers in Semi-Arid West Africa. April 2-5 1985, Purdue University, West Lafeyette.pp 123-136

Akande, M.O., Makinde, E.A., Oluwatoyinbo, F.I. and Adetunji, M.T. (2010). Effects of phosphate rock application on dry matter yield and phosphorus recovery of maize and cowpea grown in sequence. Afr. J. Environ. Sci. Technol., 4(5): 293-303
Ali J., Bakht J., Shafi M., Khan, S. and Shah, W.A. (2002). Uptake of nitrogen as affected by various combinations of nitrogen and phosphorus. Asian $J$. Plant Sci. 1: 367-369

Ayinde, I.A., Aminu, R.O. and Ibrahim, S.B. (2015). Technical efficiency of maize production in Ogun State, Nigeria. Journal of Development and Agricultural Economics, 7(2): 55-60

Ayodele, O.J. and Omotosho, S.O. (2008). Nutrient management for maize production in soils of the savannah zone of southwestern Nigeria. International Journal of Soil Science, 3: 20-27

Ayub M., Nadeem M. A.,Sharar M.S. and Mahmood N. (2002). Response of maize (Zea mays L.) fodder to different levels of nitrogen and phosphorus. Asian $J$. Pl. Sci. 1:352-354

Bray, R.H and Kurtz, L.T. (1945) Determination of total, organic and available forms of phosphorus in soils. Soil Science, 59 (1):39-45

Buresh, R.J., Sanchez,P.A. and Calhoun, F. (1997). Replenishing soil fertility in Africa. SSSA Spec. Publ. 51. SSSA and ASA, Madison, WI.

Chesin, L. and Yien, C.H. (1951). Turbidimetric determination of available sulphur in soil. Soil Science Society of America Proceedings 15:149-151

Choudhary, H.P. and Das, S.K. (1996). Effect of P, S and Mo application on yield of rain-fed blackgram and their residual effect on safflower and soil and water conservation in eroded soil. J. Indian Soc. Soil Sci., 44: 741-745

Fabunmi, T.O. and Agbonlahor, M.U. (2012). The economics of maize production under different cowpea-based green manure practices in the derived savanna zone of Nigeria. Journal of Organic Systems 7(2): $5-14$

Fajemisin, J.M. (1991). Approaches to increased production of early maturing maize in semi-arid West Africa. Paper Presented at the Proceeding of IFS Regional Seminar on Influence of Climate on the Production of Tropical Crops, Ouagadougou, Burkina Faso, 23-28 September (pp. 225-231

FAO (2013). FAO STAT, FAO Statistics Division. Retrieved July 7, 2013: http://fao stat3fao.org/home/index.html\#DOWNLOAD

FAO (2014). Crop Production statistics. FAOSTAT. www.faostat3.org

Fazli, I.S., Jamal, A., Ahmad, S., Masoodi, M., Khan, J.S., Abdin, M.Z. (2008) Interactive effect of sulphur and nitrogen on nitrogen accumulation and harvest in oilseed crops differing in nitrogen assimilation potential. J. Plant Nutri., 31: 1203-1220

FMANR (Federal Ministry of Agriculture and Natural Resources) (1990). Literature review on soil fertility investigation in Nigeria (in five volumes). FMANR, Lagos. pp. 35-45

Gee, G.W. and Bauder, J.W. (1986). Particle-size analysis. In: Methods of Soil Analysis. Klute A. (Ed.), Part 1. (2nd edn.) Agronomy 9: 383-399

Iken, J.E. and Amusa, N.A. (2004). Maize research and production in Nigeria. Afr J. Biotechnol. 3 (6): 302-307 
Isitekhale, H.H.E., Aboh, S.I., and Oseghale, E.S. (2013). Sulphur Status of Some Soils in Edo State, Nigeria. Int. J. Scientific Technol. Res., 2(5): 91-95

Islam, M.N., Hoque S. and Islam A. (2006). Effect of P and $S$ interactions on nutrient concentration and yield of wheat, rice and mungbean. J. Indian Soc. Soil Sci., 54:86-91

Jaliya, M.M., Sani, B.M., Babaji, B.A., Sani, Y.A., Sharifai, A.I. and Zongoma, A.M. (2015). Effect of interaction between nitrogen,sulfur and variety on maize grain Nitrogen and sulfur content at Samaru, Zaria. Int. J. of Sci. Nature. 6(2): 219-223

Jaliya, M.M., Chiezey, U.F., Tanimu, B., Odunze, A.C., Othman, M.K., Babaji, B.A. Sani, B.M. and Mani, H. (2012). Effects of Nitrogen and Sulfur fertilizers on Nitrogen content in soil, ear leaf, flag leaf and grain of QPM maize varieties at Samaru Zaria. Journal of Agricultural Science, 4(5): 217-222

Karimizarchi, M. Aminuddin, H., Khanif M.Y. and Radziah, O. (2014). Elemental Sulphur Application Effects on Nutrient Availability and Sweet Maize (Zea mays L.) Response in a High pH Soil of Malaysia. Malaysian Journal of Soil Science. 18: 75-86

Kumawat, B. L, Pathan ARK and Chahan R. (2004). Response of taramirra to sulphur and phosphorus application on TypicPasmmnt. J. Indian Soc. Soil Sci., 52: $476-478$

Muhammad R, Hakoomat A, and Triq, M. (2004). Impact of Nitrogen and Sulfur application on growth and yield of maize (Zea mays L.) crop. Journal of Research (Science), 15(2): 153-157

Muhammad, I., Muhammad, J.K., Amjad, A.1., Amanullah, J. and Sajida P. (2015). Effect of Phosphorus and Sulfur on the yield and nutrient uptake of maize. International Journal of Farming and Allied Sciences, 4(3): 244-252

Olaniyan, A.B. (2015). Maize: Panacea for hunger in Nigeria. Afr. J. Plant Sci., 9(3) 155-174.

Onasanya, R.O., Aiyelari, O.P., Onasanya, A., Oikeh, S. Nwilene F.E and Oyelakin, O.O. (2009). Growth and yield response of maize (Zea mays L.) to different rates of nitrogen and phosphorus fertilizers in southern Nigeria. World J. Agric. Sci. 5 (4): 400-407

Oyakhilomen, O. (2014). Gender influence on the income of maize farmers in Giwa local government area of Kaduna State. Russian Journal of Agricultural and Socio-Economic Sciences, 1(25):14-18

Rajan, S.S.S, Watkinson,J.H. and Sinclair,A.G (1996). Phosphate rocks for direct application to soils. Advances in Agronomy, 57:77-159
Ray R.W. and Mughogho, S.K. (2000). Sulphur nutrition of maize in four regions of Malawi. Agronomy Journal, 92: 649-656

Shapiro, C.A., Ferguson, R.B., Hergert, G.W., Dobermann, A. and Wortmann, C.S. (2003). Fertilizer suggestions for corn. NebGuide G74-174-A. Univ. of Nebraska Coop. Ext. Service, Lincoln

Taalab, A.S., Hellal, F.A. and Abou-Seeda, M.A. (2008). Influence of phosphate fertilizers enriched with sulfur on phosphorus availability and corn yield in calcareous soil in arid region. Ozean Journal of Applied Sciences, 1(1):105-115

Tandon, H.L.S. (1989). Sulphur Fertilizer for Indian Agriculture: A Guide Book. Fertilizer Organization, C110 Greater Kailash-1; New Delhi-110048, India. pp 1-4

Thomas, G.W. (1982). Exchangeable cations. In: Methods of Soil Analysis, Part 2. Page, A.L., Miller, A. and Keeney, D.R. (Eds.). 2nd Edn. Monogragh No 9, ASA and SSSA, Madison, WI. pp:159-166

Tiwari, K.N. and Gupta, B.R. (2006). Sulphur for sustainable high yield agriculture in Uttar Pradesh. Indian J. Fert., 2: 37-52

Uzoh, I.M., Obalum, S.E. and Ene, J. (2015). Mineralization rate constants, half-lives and effects of two organic amendments on maize yield and carbonnitrogen status of loamy Ultisol in Southeastern Nigeria. Agro-Science, 14(3): 35-40

Walkley, A. and Black, A. (1934). An examination of the degtrareff method for determining soil organic matter and a proposed modification of the chromic acid titration method. Soil Sci., 37: 29 -38

Weil, R.R. and Mughogho, S. K. (2000). Sulphur nutrition of maize in four regions of Malawi. Agronomy Journal, 92: 649-656

Wortmann, C.S., Dobermann, A.R., Ferguson R.B., Hergert, G.W., Shapiro C.A., Tarkalson, D.D. and Walters, D.T. (2009). High-yielding corn response to applied phosphorus, potassium, and sulfur in Nebraska. Agronomy Journal, 101(3): 546-555

Wortmann, C.S., Xerinda, S.A., Mamo, M. and Shapiro, C.A. (2006a). No-till row crop response to starter fertilizer in eastern Nebraska: I. Irrigated and rainfed corn. Agron. J. 98: 156-162

Wortmann, C.S., Xerinda, S.A. and Mamo, M. (2006b). No-till row crop response to starter fertilizer in eastern Nebraska: II. Rain-fed grain sorghum. Agron. J. 98: 187-193

Yusuf, A.A., Chude, V., and Janassen, B.H. (2003). Response of rice (Oryza sativa L) to phosphate fertilizers varying in solubility. Afr. Soils, 33: 57-72 